\title{
Hydrological Variations Associated with Geomorphological Changes in a Sand Dune Barrier of the Partido de La Costa, Province of Buenos Aires
}

\author{
Silvina Carretero and Eduardo Kruse
}

\begin{abstract}
The evolution of land use in San Clemente del Tuyú and Santa Teresita (Partido de La Costa [La Costa District], Buenos Aires, Argentina) is analysed in association with the increase in population and the presence or absence of a water supply service, in order to assess changes in the hydrological system through time. A multi-temporal analysis was undertaken on Landsat satellite images, differentiating types of land use. Water balances were estimated, and the recharge for each situation was evaluated. An increase in urbanized surface at the expense of the natural sand dune environment can be observed, which entails larger impervious surfaces that are unsuitable for the infiltration and recharge of the aquifer. In both areas, a decrease in groundwater reserves occurred; in Santa Teresita, there was even a deterioration in the chemical quality of water due to sea water intrusion. It can be concluded that the urbanization process has had a negative impact on the water system in the sand dune barrier area, affecting the infiltration and recharge processes. The presence of managed supply systems acquires relevance as a conditioning factor to avoid saltwater intrusion processes. It is essential to implement land-use planning strategies that would protect the areas unaffected by urbanization that may be of use as a reservoir for the future supply of freshwater.
\end{abstract}

Keywords Land use - Freshwater reserves - Anthropogenic modifications • Argentina

\footnotetext{
S. Carretero $(\bowtie) \cdot$ E. Kruse

Facultad de Ciencias Naturales y Museo, CONICET and Universidad Nacional de La Plata, Cátedra de Hidrología General. Calle 64 №3, La Plata, Argentina

e-mail: scarretero@fcnym.unlp.edu.ar 


\section{Introduction}

Coastal sand dunes can be found in a wide variety of climate regimes, and their formation depends on the availability of sand and on the winds, with vegetation development having a role in their fixation (de Seoane et al. 2007). In many cases, these environments have been degraded by anthropogenic activities-which increased significantly in the last 50 years - as it happened in New Zealand and the Netherlands, where many of the coastal systems are irreversibly altered or have disappeared (Martínez et al. 2008). Coastal dunes comprise approximately 15\% of the world's coasts, with the largest barriers coinciding with tectonically stable margins, such as the east coast of the USA $(3100 \mathrm{~km})$ and the Gulf of Mexico coast $(1600 \mathrm{~km})$. There are also barrier chains along the east coast of South America $(960 \mathrm{~km})$, the east coast of India $(680 \mathrm{~km})$, the North Sea in Europe $(560 \mathrm{~km})$, the east of Siberia $(300 \mathrm{~km})$ and the north of Alaska $(900 \mathrm{~km})$ (FitzGerald and Buynevich 2006).

Due to their morphological characteristics and infiltration capacity, coastal dunes constitute groundwater recharge areas and freshwater reservoirs. In many cases, these reservoirs are the only source of supply to the coastal population and they act as barriers protecting from sea water intrusion (Martínez and Vázquez 2006).

There are examples of sandy coasts where aquifers have been studied, monitored and managed, for instance in the Netherlands, Belgium, the south of Italy and north-east Spain. Coastal aquifers are often of small magnitude, but they acquire relevance in the coverage of human needs, ranging from urbanization to irrigation (Custodio 2010).

Coastal aquifers have certain characteristics that make them significant from the point of view of the genesis and functioning of the natural spaces related to them. They tend to be environment with high morphological dynamism in permanent evolution. This causes morphological changes (the ones at a smaller scale are perceptible at a human timescale) that generally have an impact on the configuration of the hydrographical network and its relationship with groundwater: the quantity, location and/or extension of the aquifer recharge, discharge areas, channel route and flow volume (Manzano 2002).

Land use, particularly in urban areas and concerning its relationship with groundwater quantity and quality, has been widely addressed (Bellot et al. 2007; Houlahan and Findlay 2004; Kim 2004; Kim et al. 2003; Park et al. 2005; Weng 2001; Zuquette et al. 2004). The general influence of urbanization on the hydrological cycle includes the increase in surface run-off along roofs, pavements, streets, etc. that may drain towards the main network or main receiving body (Basile and Riccardi 2000), the modification of the natural fluctuations in groundwater levels (Batrak and Semenov 2008), the decrease in natural infiltration and the alteration of the surface run-off processes (Kruse et al. 2004).

Even though it is assumed that recharge related to precipitations decreases due to the increase in impervious surfaces in an urban area, different studies state that it may be maintained or that it may rise despite the increase in impervious areas. 
Infiltrating water may come from surfaces with secondary permeability (road surfaces, pavements, car parks), infiltration ponds, irrigation, losses from the sewage system and freshwater supply system (Lerner 2002; Lerner and Barrett 1996; Hibbs and Sharp 2012; Sharp 2010; Sharp et al. 2013; Wiles and Sharp 2008). However, Seiler and Gat (2007) present other studies in which they observe a decrease of over $10 \%$ in the recharge due to drainage discharging into the sea.

In South America, aquifers in coastal dunes coincide with the deposits of the Atlantic coast (Rebouças 1999). Bocanegra et al. (2010) indicate the presence of small clastic aquifers occurring in dunes, of local interest, which are strategic water reservoirs. The most serious supply problems arise in coastal aquifers located in highly populated areas in south-east Brazil, extending towards north-east Uruguay (Almagro and Custodio 2004).

The eastern coast of the Province of Buenos Aires could be included among those places with the above-mentioned characteristics. From the mid-twenty-first century, this region has experienced a strong demographic increase, with a chaotic urbanization process and expansion of the economic activities, especially those related to the numerous seaside resorts, which led to a higher freshwater supply requirement (Kruse et al. 2012). This urban growth has contributed to the modification of the environment and, therefore, of the distribution concerning both land use and hydrological behaviour. In this region, the only source of drinking water (groundwater) shows limited development and is restricted to the water table occurring in the dune fringe (Carretero 2011). Besides the anthropogenic factor, this region is vulnerable to coastal erosion and saltwater intrusion, especially related to high-energy storm waves associated with strong south-easterly winds ("sudestadas") (Pousa et al. 2007). The excessive exploitation of the resource due to the lack of domestic water service has brought sea water intrusion problems (Carretero et al. 2013c; Perdomo et al. 2013). Another factor to be taken into consideration is the rise in sea level related to climate change, which may affect the hydrogeology of the region in the future (Carretero et al. 2013a).

In the sandy coast of Buenos Aires, it is useful to establish the relationships between the changes in land use and groundwater quantity and quality, as the increase in stable population, together with the arrival of tourists in the summer months, is intimately linked to the consumption and management of water reserves.

In the study area, the processes of urbanization, dune destruction and soil becoming impervious affect the groundwater regime, as a consequence of the decrease in infiltration and the restriction of recharge areas (Carretero and Kruse 2010, 2014; Carretero et al. 2014). The process of urbanization to varying degrees, which brings about a decrease in possibilities for water excess infiltration restricts the natural recharge areas of the aquifer and, therefore, the available freshwater reserves.

The lack of hydrogeological data is a problem affecting the study, knowledge and understanding of coastal aquifers in South America. Bocanegra et al. (2010) point out the lack of characterization studies to support the planning and management of resources, and the lack of observation networks. In Argentina, 
according to a report on water management (Planas et al. 2000), there is no database or information system on water resources, neither at a national or provincial level, which may support the management.

This situation is not unlike the one in the coast of the Province of Buenos Aires, where the lack of hydrogeological data - both historical and current - and the lack of an integral monitoring network at a regional level make it necessary to use tools and methodologies - such as the use of satellite images, which has already been applied for several decades (Byrne et al. 1980) - to recognize variations in water resources and to analyse variations in coastal regions (Huang et al. 2012; Kuleli et al. 2011; Ray et al. 2012; Shalaby and Tateishi 2007).

In this work, the evolution of land use in two localities in the Partido de La Costa [La Costa District] is analysed in association with population growth and the presence or absence of a water supply service, in order to assess changes in the hydrological system along time.

\section{Study Area}

The localities of San Clemente del Tuyú and Santa Teresita (Partido de La Costa, Buenos Aires) are located on a sand dune barrier (Fig. 1a). It should be noted that the inhabitants depend for the supply of water on a phreatic aquifer occurring in the above-mentioned coastal barrier, which is limited to the east and west by marine salt water and continental brackish water, respectively. The recharge to the water system only occurs by infiltration of precipitation excesses (Carretero 2011). Most of the localities in the Partido de La Costa have no drinking water service, and their inhabitants are supplied by means of individual domestic wells, with no water treatment or control of the volumes extracted. The sewage system has a wider distribution in the most important localities. It is believed that there are no significant losses from the water supply network that would feed the water table, as the network is in general in good condition and has been functioning for less than 20 years; the same applies to the sewage system.

The predominant economic activity is tourism: there are no industries, livestock farming, agriculture, or other important activities, which is why it is believed that water use is exclusive for human consumption. The population, which depends solely on the coastal aquifer for water supply, increases significantly during the summer.

The climate is humid temperate, with a dry season during the cold months (April-September) and a rainy season during the warm months (October-March). The mean annual precipitation fluctuates between 900 and $1000 \mathrm{~mm}$, with $60 \%$ occurring in the months with higher evapotranspiration, which is why the highest recharge takes place during the dry season (Carretero and Kruse 2012).

The sand dune barrier extends along $70 \mathrm{~km}$ between Punta Rasa, to the north, and Punta Médanos, to the south, with a width ranging from 2 to $4 \mathrm{~km}$. It borders to 


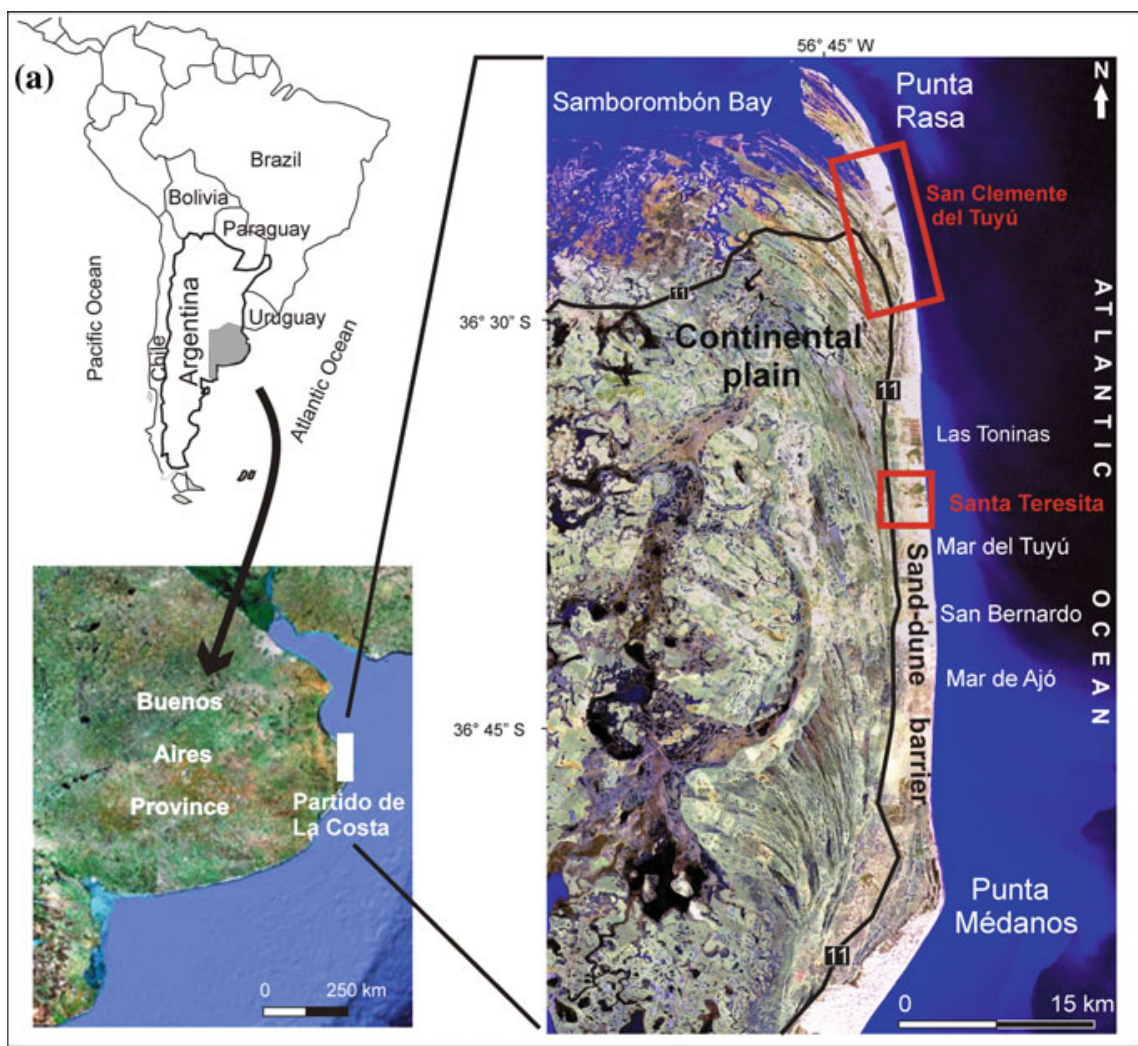

(b)

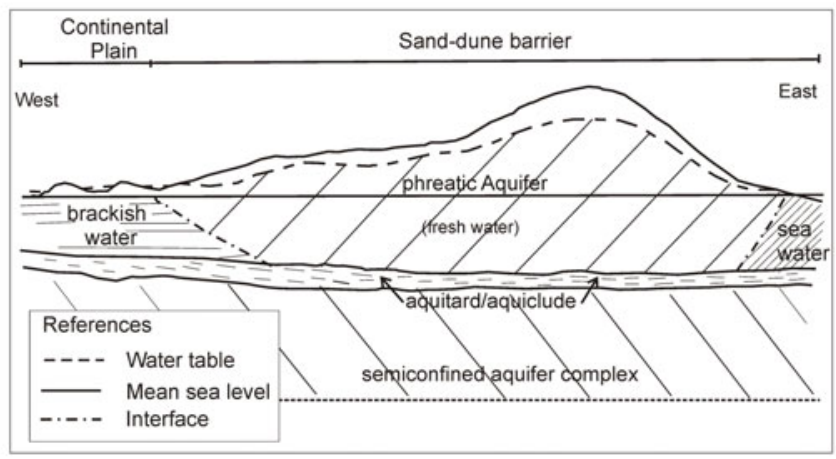

Fig. 1 a Study area. b General hydrodynamic diagram

the west with the continental plain, which is characterized by heights lower than 2 m.a.s.l. and the predominance of silty and clayey materials, with gullies oriented in a south-east-north-west direction, draining towards the Samborombón Bay. 
The sand dunes in the barrier are low, with heights between 2 and 11 m.a.s.l., and fixed by sparse vegetation. In this environment, soils are sandy, with no horizon development, excessively drained and unstable.

The hydrodynamic and hydrochemical behaviour of groundwater is conditioned by the geomorphological environment. In the sand dune barrier, the water is of low salinity and mainly of the $\mathrm{Ca}-\mathrm{HCO}_{3}$ type, whereas in the continental plain the water shows high salinity and is of the $\mathrm{Na}-\mathrm{Cl}$ type (Carretero et al. 2013b). The high $\mathrm{Fe}$ and $\mathrm{Mn}$ concentrations represent the greatest problem as regards the chemical quality in the region (Carretero and Kruse 2015).

The sand dune barrier is the main recharge area for groundwater, which then flows along a short stretch and discharges in two opposite directions: towards the sea and towards the continental plain to the west (Fig. 1b). The main freshwater aquifer is composed of dune sands (aeolian sediments) overlying barrier sands of variable thickness - between 7 and $20 \mathrm{~m}$, depending on the height of the dunesand it is bounded by two interfaces: a freshwater-brackish water interface towards the continent and a freshwater-saltwater interface towards the sea; this unit overlies aquitard/aquiclude sediments. In the Punta Médanos sector, an underlying semi-confined aquifer composed of sand and silty-clayey sand can be recognized; this unit overlies plastic clays.

\section{Methodology}

Fieldwork was undertaken, and the geomorphological, hydrogeological and land-use characteristics were assessed. Based on the contribution by Carretero et al. (2014), the areas of interest in the Landsat TM satellite images were selected for 1986 and 2010. This selection was based on the fact that there are historical data (CFI 1990) and current samplings (2012) that made it possible to draw isophreatic curve and electric isoconductivity maps.

A multi-temporal analysis was carried out on Landsat TM satellite images with a spatial resolution of $30 \mathrm{~m}$, which were obtained from USGS/EROS (Earth Resources Observation and Science, http://glovis.usgs.gov). Each of the images consists in two scenes from February, in order to compare appropriately the maps and avoid introducing errors due to seasonal variation.

The images were rectified radiometrically with the gain and offset values from the metadata file, following Chander et al. (2009), and subsequently corrected geometrically before mosaicking using a WGS84 datum and UTM projection with ENVI $^{\mathrm{TM}}$ software (Exelis VIS). It was not necessary to apply an atmospheric correction, as the multi-date classification procedure was carried out using spectral features obtained from each image (Song et al. 2001). In order to map land cover/ land use, a decision tree classification algorithm was used. Each pixel was assigned to one of the six classes of pixels with similar spectra by means of a series of binary splits. The classes are bright sand, dark sand, dense vegetation, sparse vegetation, 
bare soil and urbanized area. A statistical analysis was applied to every set, and a comparison of the mean radiance spectra was undertaken to corroborate class separation.

The study area was delimited to the localities of San Clemente del Tuyú and Santa Teresita, using Ruta Nacional 11 (National Route 11) as a limit to the west and the sea to the east. The output layers were manually reprocessed with a GIS (geographic information system) tool; and based on images and field surveys, four classes corresponding to the more significant land uses (mobile dune, semi-fixed dune, fixed dune and urbanized area) were determined. The changes that took place in the sand dunes were evaluated by calculating the areas affected by such changes and the percentage variations for each land-use type across the years studied.

The water balances were estimated by means of the methodology proposed by Thornthwaite and Mather (1955), based on precipitation data from the Servicio Meteorológico Nacional (SMN; National Weather Service of Argentina) station in Santa Teresita and a rain gauge set in San Clemente del Tuyú. Data from nearby stations, which are located outside the study area, have been added in order to have a more detailed outlook on the water balances at a regional level. Daily mean $\mathrm{ET}_{0}$ (reference evapotranspiration) values, estimated according to Penman-Monteith (Allen et al. 1998), were used.

An infiltration value was assigned to each type of land use, and the recharge for each situation was evaluated. Besides, population growth was considered, analysing the statistics of the INDEC $(1981,2010)$ for the localities of the Partido de La Costa. Based on such data, the mean annual water demand for the region was estimated. Considering $200 \mathrm{~L} / \mathrm{d}$ as average consumption (Planas et al. 2000), the volume necessary to supply the permanent inhabitants was calculated.

\section{Land Use and Its Evolution}

The analysis of satellite images resulted in a territory classification into four classes of land use: mobile dune, semi-fixed dune, fixed dune and urbanized area (Fig. 2). In the first three classes, the sandy substrate is preserved and covered by different percentages of vegetation.

The mobile dune occurs adjacent to the beach, along the coastline towards the west, and it maintains its natural transport dynamics due to the winds from the east. Although the presence of vegetation can be observed, it is very sparse and shows no signs of urbanization.

Slightly farther from the coast occurs the semi-fixed dune, showing a higher percentage of vegetation, which is capable of retaining sand. This fixation process represents the natural evolution of the mobile dune towards the semi-fixed dune. In some sectors, although the vegetation is not so abundant, the fixation phenomenon occurs due to sand compaction, as is the case in roads and streets, which constitutes a case of anthropogenic modification. The percentage of houses or urbanization features is minimal. 


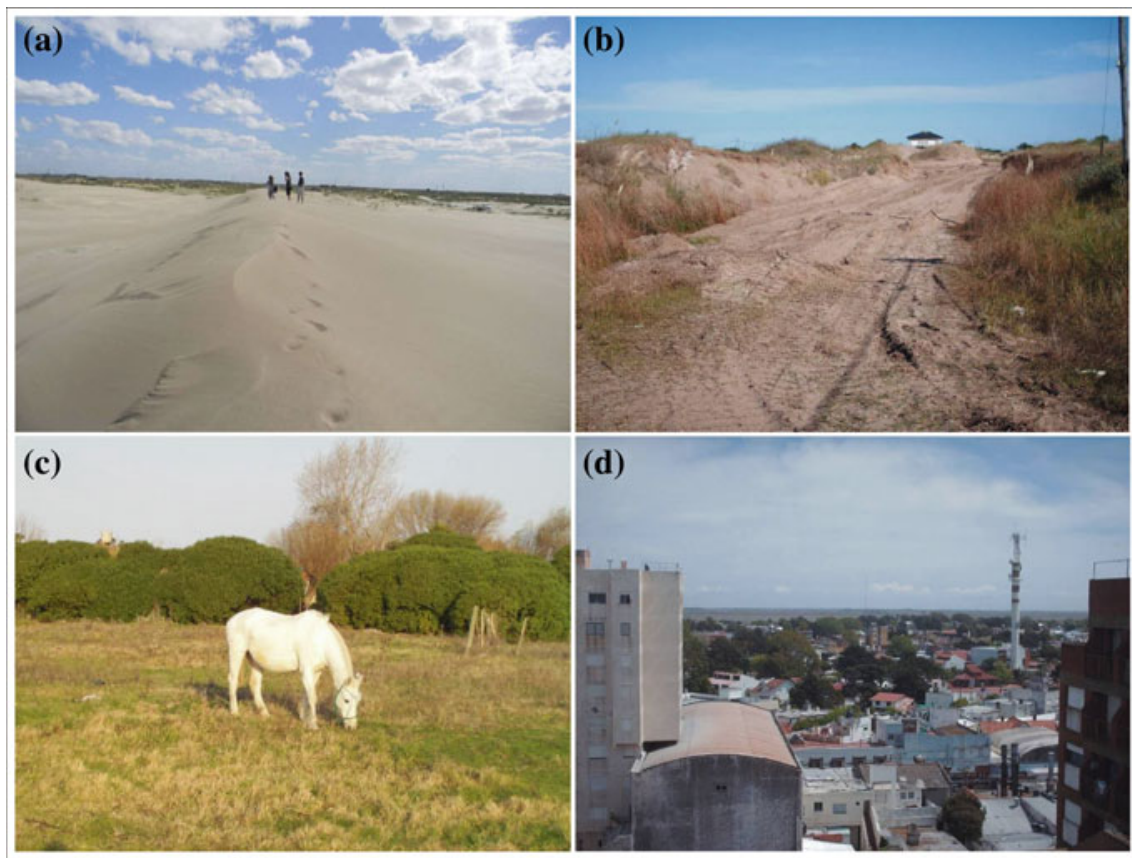

Fig. 2 Land-use classification a mobile dune, $\mathbf{b}$ semi-fixed dune, $\mathbf{c}$ fixed dune and $\mathbf{d}$ urbanized area

The area classified as fixed dune is located further into the continent and is covered by abundant vegetation. As in the semi-fixed dune, the signs of anthropogenic alteration are minimal.

Finally, the class comprising the urbanized areas, where the natural characteristics of the dune cannot be observed, was defined. This is the sector that has been modified the most with respect to the natural environment: It is composed of buildings and - in certain areas - paved streets, which represent practically impervious surfaces.

In the image analysis (Fig. 3), an increase in urbanized surfaces at the expense of the natural sand dune environment can be observed, implying larger impervious surfaces unsuitable for the infiltration and recharge of the aquifer. Although this process can be recognized in both localities, it is of a larger magnitude in Santa Teresita than in San Clemente del Tuyú (Table 1). On the other hand, the mobile dune has practically disappeared in Santa Teresita, replaced by the urban grid, whereas in San Clemente it is only partially reduced. A slight advance of the fixed dune (vegetation) over the mobile dune can be observed, interfingered with the semi-fixed dune in certain sectors, which is part of the natural process of evolution of the sand dune barrier. 


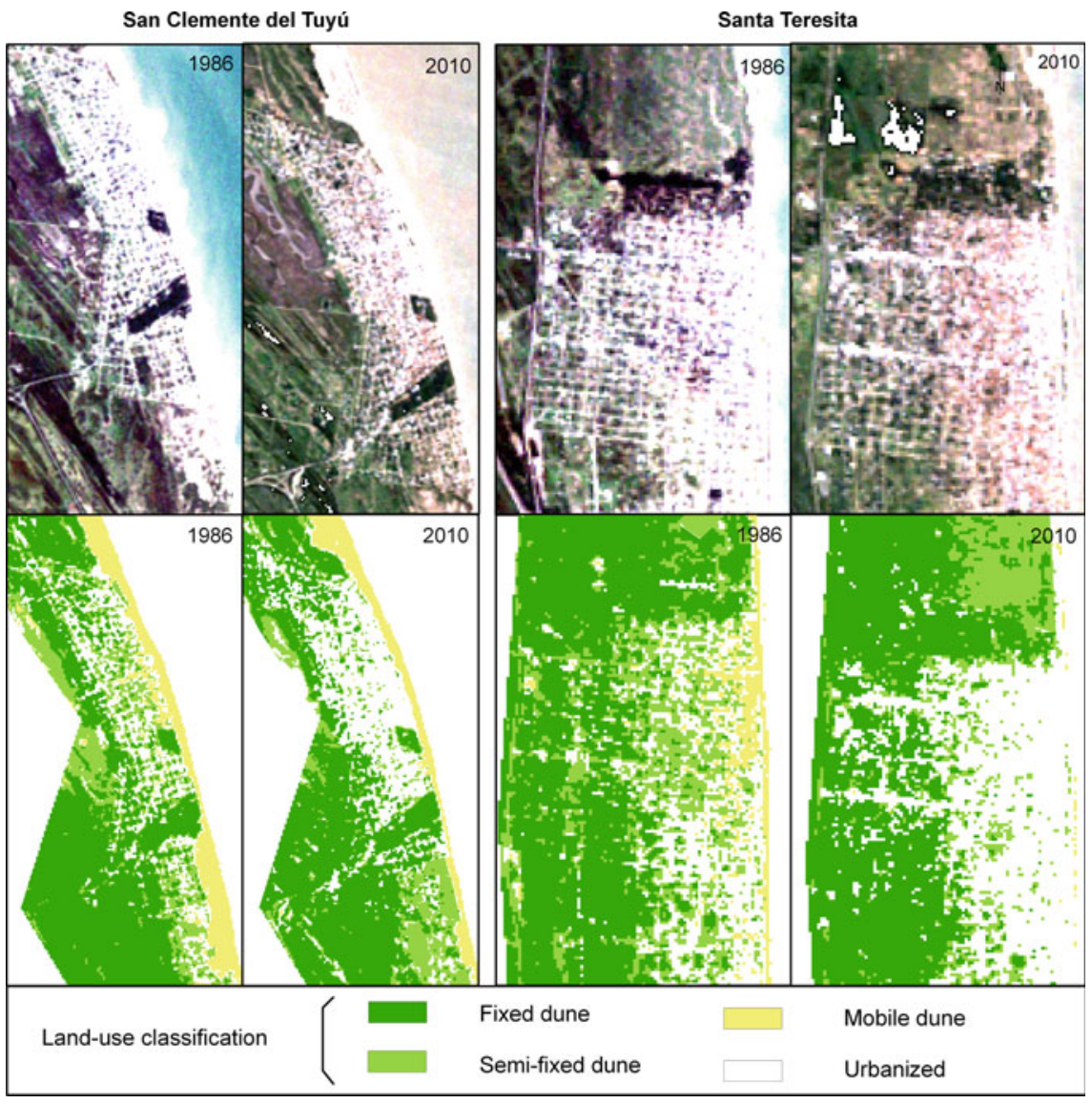

Fig. 3 Land-use changes between 1986 and 2010

Table 1 Area, estimated recharge and variation percentage corresponding to the land-use classification for the years studied

\begin{tabular}{l|l|l|l|l|l|l}
\hline & & \multicolumn{2}{l|}{ Area $\left(\mathrm{km}^{2}\right)$} & \multicolumn{2}{l|}{ Recharge $\left(\mathrm{hm}^{3}\right)$} & Variation $(\%)$ \\
\cline { 2 - 7 } & & 1986 & 2010 & 1986 & 2010 & $2010-1986$ \\
\hline \multirow{3}{*}{ San Clemente } & Mobile dune & 2.06 & 1.24 & 0.9 & 0.6 & -40 \\
\cline { 2 - 7 } & Semi-fixed dune & 3.41 & 2.95 & 1.2 & 1.0 & -14 \\
\cline { 2 - 7 } & Fixed dune & 9.54 & 9.40 & 2.97 & 2.9 & -1 \\
\cline { 2 - 7 } & Urbanized & 1.97 & 3.40 & 0.13 & 0.2 & 72 \\
\cline { 2 - 7 } & Total & 17.0 & 17.0 & 5.2 & 4.7 & -9 \\
\hline \multirow{5}{*}{ Santa Teresita } & Mobile dune & 0.57 & 0.03 & 0.3 & 0.01 & -95 \\
\cline { 2 - 7 } & Semi-fixed dune & 2.07 & 1.78 & 0.7 & 0.6 & -14 \\
\cline { 2 - 7 } & Fixed dune & 4.17 & 3.58 & 1.3 & 1.1 & -14 \\
\cline { 2 - 7 } & Urbanized & 1.22 & 2.64 & 0.1 & 0.2 & 117 \\
\cline { 2 - 7 } & Total & 8.0 & 8.0 & 2.4 & 1.9 & -18 \\
\hline
\end{tabular}




\section{Modifications to the Hydrological System}

The only water input into the aquifer comes from precipitations. The water balances (Table 2) and Carretero and Kruse (2010) show that there is no appreciable climate variability, with a mean annual precipitation of $968 \mathrm{~mm}$ and a water surplus of $444 \mathrm{~mm}$, which-through infiltration-constitute the only recharge to the groundwater system.

The comparative analysis of the water-table contour maps (Fig. 4) shows that in San Clemente, the curves fluctuate between 0.5 and 2.5 m.a.s.1., both for 1987 and 2012. However, it can be observed that the contour of 1 m.a.s.l. is displaced towards the interior, and an areal reduction in the contours of 1.5 and 2.5 m.a.s.1. occurs in the period studied.

In Santa Teresita, water-table heights vary from 1.5 to 5 m.a.s.l. in 1987, with a decrease by 2012 to 1 and 3.5 m.a.s.l.

These changes in phreatic morphology are evident in the water-level change map (Fig. 5), where the highest generalized decrease in the levels $(2.5 \mathrm{~m})$ can be observed in Santa Teresita.

On the other hand, the hydrochemistry (Fig. 6) indicates that in Santa Teresita, a saltwater intrusion phenomenon has occurred in certain sectors along Avenida Costanera (Coastal Avenue), whereas in San Clemente del Tuyú the chemical quality has remained within the same parameters throughout the period analysed.

Depending on the area and the geomorphological characteristics of each of the land-use classes, a percentage of infiltration of the water excesses in the water balance was defined for each class. In the mobile dune, the infiltration of the water excesses occurs over $100 \%$ of its surface, in the semi-fixed dune in $80 \%$, whereas in the fixed dune it is reduced to $70 \%$.

According to different authors and in different cities (Auge 2005; Kruse et al. 2013; Vázquez Suñé and Sánchez-Vila 1997; Wiles and Sharp 2008), urbanized areas have been assigned infiltration values ranging from 6 to $36 \%$ of the precipitations. As regards this case study, it is assumed that $15 \%$ of the excess infiltrates over small surfaces and the rest constitutes surface run-off discharging into the sea.

Table 2 Average water balance. Values are expressed in $\mathrm{mm} /$ year. PET (potential evapotranspiration), ETr (real evapotranspiration)

\begin{tabular}{l|l|l|l|l|l}
\hline Station & Period & Precipitation & PET & ETr & Water surplus \\
\hline Punta Indio & $1925-2008$ & 965 & 747 & 523 & 441 \\
\hline Dolores & $1959-2008$ & 944 & 690 & 519 & 424 \\
\hline Santa Teresita & $1990-2007$ & 995 & 684 & 525 & 468 \\
\hline San Clemente & $2003-2012$ & 911 & 698 & 472 & 436 \\
\hline Average & & 968 & 707 & 522 & 444 \\
\hline
\end{tabular}




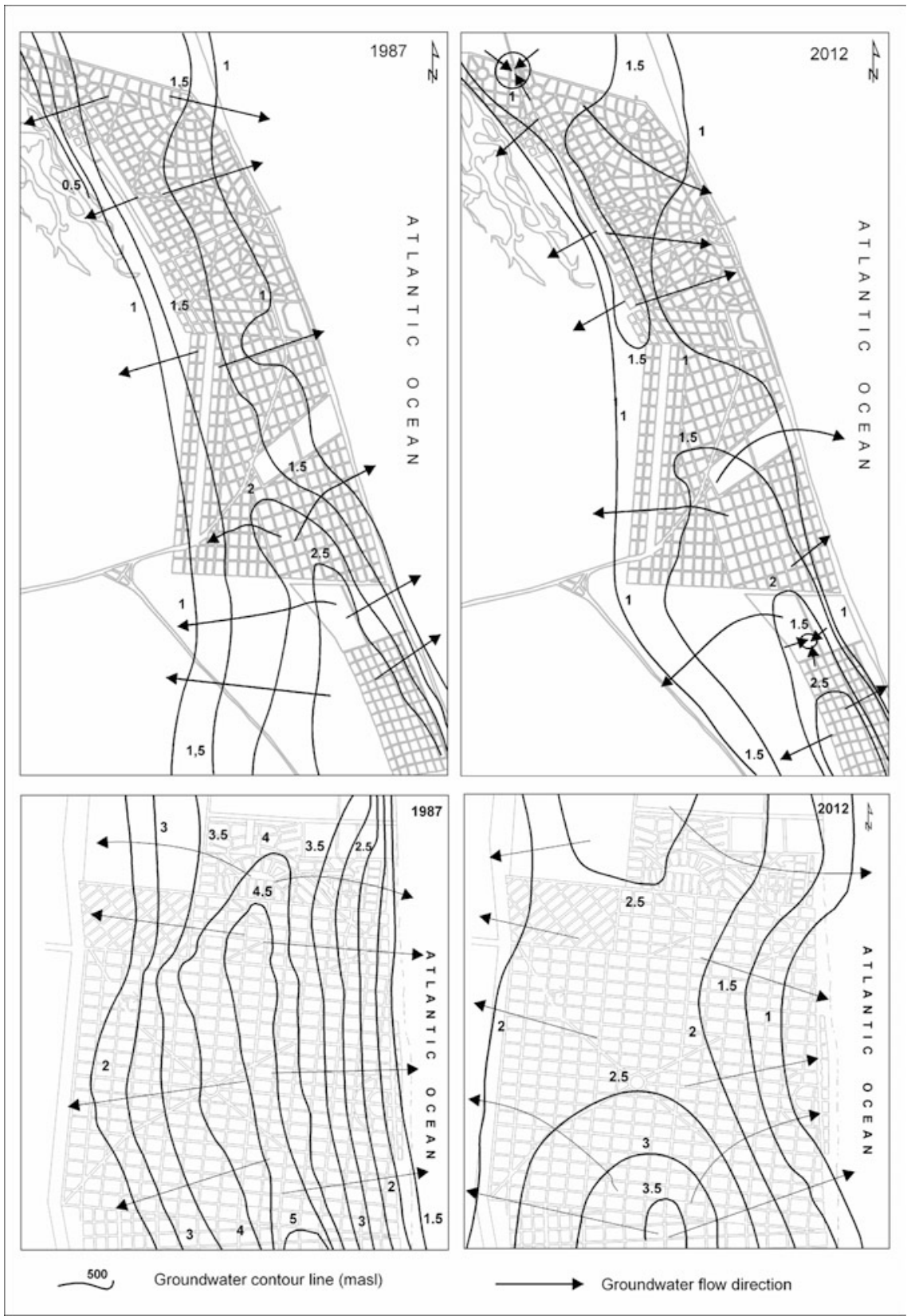

Fig. 4 Water-table contour maps: San Clemente (above) and Santa Teresita (below) 


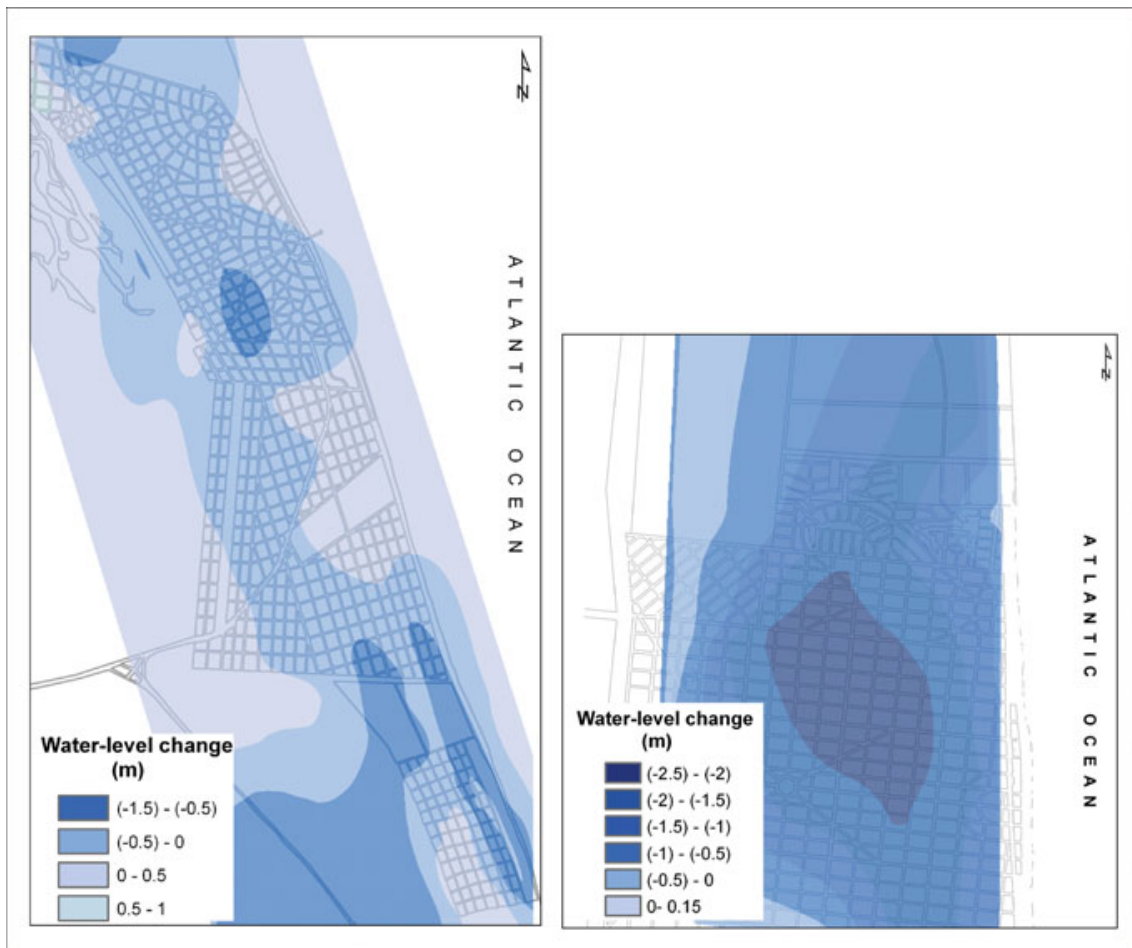

Fig. 5 Water-level change maps: San Clemente (left) and Santa Teresita (right)

Based on the areas calculated for each land use and the infiltration percentage assigned, the theoretical volume of water recharging into the aquifer and the interannual variations were estimated (Table 1).

If the variations depending on land use are considered, it can be observed that in the urbanized area, even though the numbers seem to indicate that there is an increase in recharge, this is only caused by its areal expansion. This is an apparent increase, since despite the fact that it is the sector with highest areal increase, it is also the one with the lowest infiltration capacity. At this point, the aspect to be noted is that urbanization has developed by replacing the natural sand dune environment, which has the highest infiltration capacity. This leads to a reduction in total recharge, resulting in twice as much recharge reduction in Santa Teresita compared to San Clemente.

In Santa Teresita, the groundwater reserves in the mobile dune decreased by 95\%, whereas in San Clemente they did so by $40 \%$; in the semi-fixed dune, the decrease is similar in both localities (14\%). 


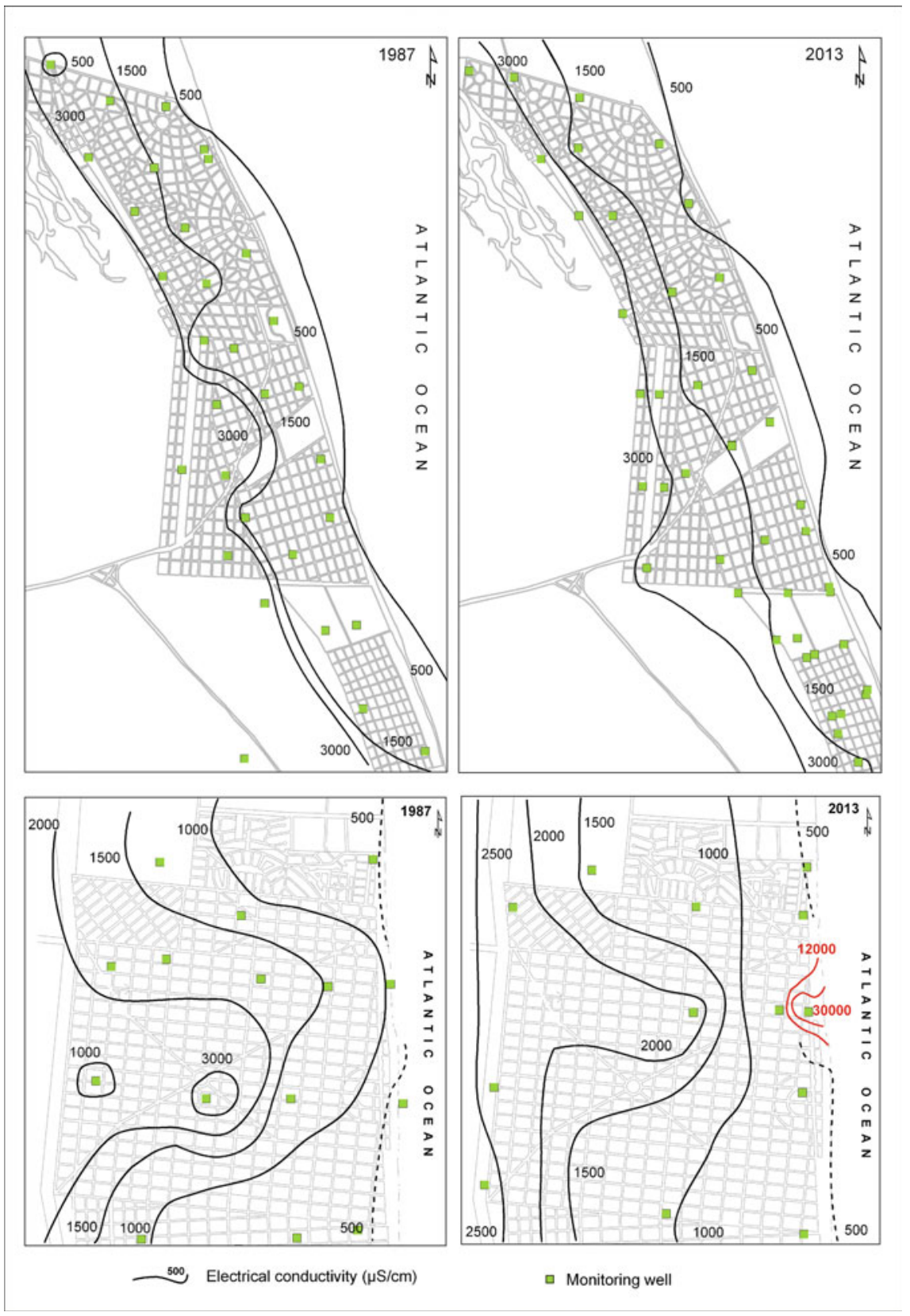

Fig. 6 Iso-electrical conductivity maps: San Clemente (above) and Santa Teresita (below) 
Table 3 Population variation and water consumption

\begin{tabular}{l|l|l|l|l|l}
\hline \multirow{2}{*}{} & \multicolumn{2}{|l|}{ Population } & Growth rate & \multicolumn{2}{l}{$\begin{array}{l}\text { Water demand } \\
\left(\mathrm{hm}^{3} / \text { year }\right)\end{array}$} \\
\cline { 2 - 3 } & 1986 & 2010 & & 1986 & 2010 \\
\hline San Clemente & 6482 & 13071 & 2.0 & 0.5 & 1.0 \\
\hline Santa Teresita & 9052 & 22943 & 2.5 & 0.7 & 1.7 \\
\hline
\end{tabular}

As well as a decrease in the reserves due to the increase in urbanized areas, a decrease associated with a growth in population and an increase in consumption in both areas occurred (Table 3). It should be noted that the chemical quality of the water has only deteriorated in Santa Teresita.

It is proposed that the conditioning factor in this case is the presence or absence of a water supply service in the localities. In San Clemente del Tuyú, the drinking water supply system mainly feeds the city centre, where the restaurants, hotels and largest buildings are located, on Avenida Costanera. The resource is obtained by means of a well system at a depth of $6 \mathrm{~m}$, from a pumping field located to the south, out of the urbanized area, in the semi-fixed dune. Wellpoint systems and Ranney wells were used, in which the extraction volumes reach 13 and $7 \mathrm{~m}^{3} / \mathrm{h}$, respectively (Fig. 7). The average daily extraction volumes in the summer fluctuate between 1500 and $1800 \mathrm{~m}^{3}$; out of season, the average is $500 \mathrm{~m}^{3}$. There is a water purification plant, where water is treated (mainly Fe and Mn abatement) for its subsequent distribution.

On the other hand, Santa Teresita lacks such a service, and most of the urban development is on the coastal road, where large buildings and hotels extracting water with no control whatsoever can be observed.

Both localities share the same geohydrological environment and water balance excesses. They also show certain percentages of impervious surfaces and a greater urban development on Avenida Costanera, which is logical given that, due to its proximity to the sea, it is a major tourist attraction. They differ in the deterioration of the chemical quality of the water, as an advance of the freshwater/saltwater interface occurs in Santa Teresita. The only variable that seems to make a difference is the absence of a water supply network in this locality. This lack implies that users must be supplied by domestic wells, with no control over the quantity and quality of the water resource extracted. At a domestic level, this scheme may not seem to be too detrimental, but the perspective changes radically when taking into consideration the presence of hotels and buildings in a location that is near the saltwater wedge and in which the number of people per unit area is high. The result is a process of sea water intrusion and a deterioration of the resource. 


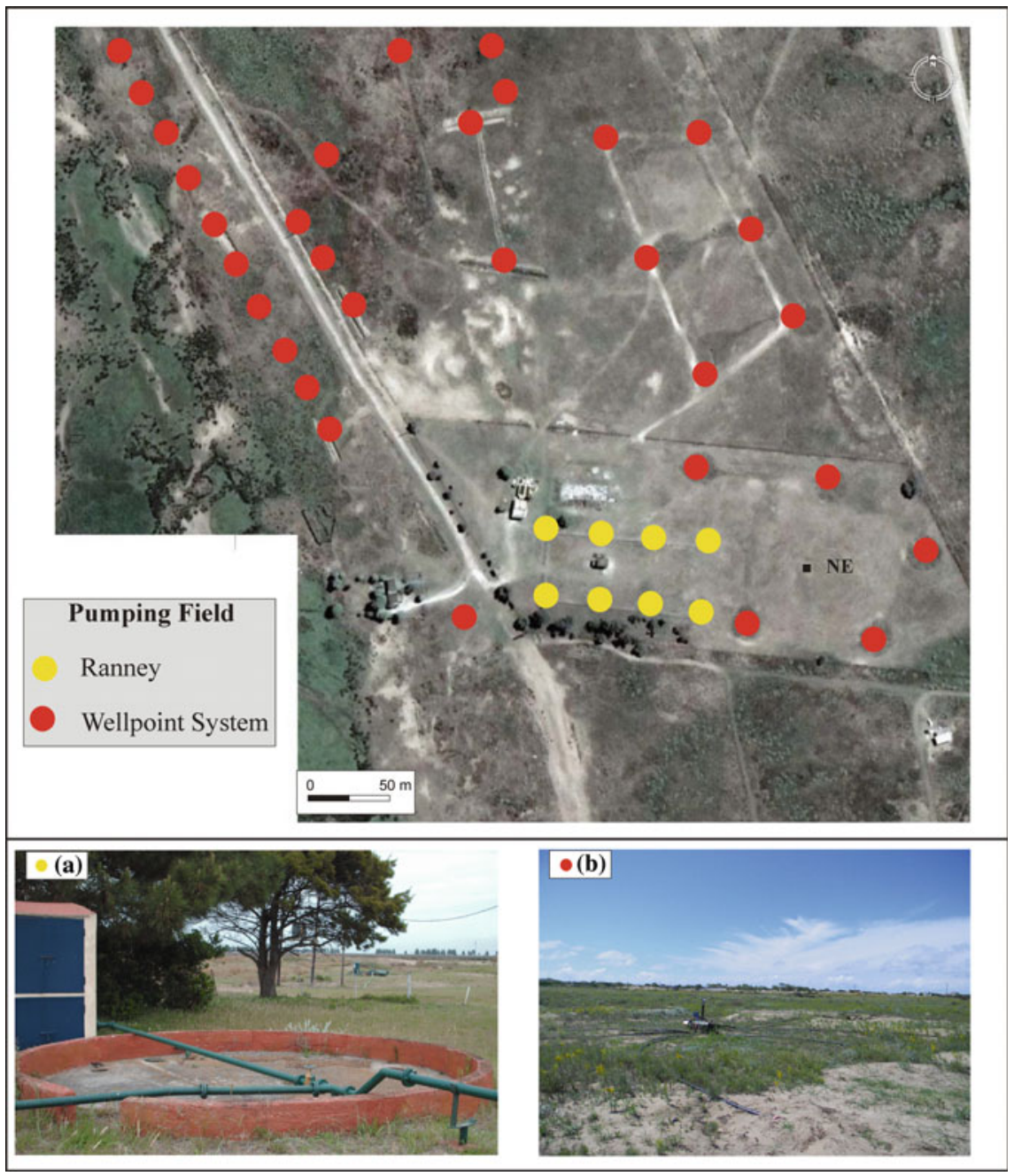

Fig. 7 Pumping field in San Clemente

\section{Conclusions}

The reduction in the mobile dune, which has been replaced by the establishment of cities in front of the sea, is noticeable. The fixed dune has replaced the semi-fixed dune in small sectors.

It can be observed that the urbanization process (impervious surfaces) has had a negative impact on the water system in sand dune barrier areas, affecting the processes of infiltration and recharge. 
According to the methodology applied, the freshwater recharge has been reduced twice as much in Santa Teresita compared to San Clemente.

The presence of controlled drinking water supply systems acquires relevance as a conditioning factor to avoid saltwater intrusion processes in seaside localities.

The implementation of land-use planning strategies is essential to protect the areas not affected by urbanization that may act as a reservoir for future supply to the population.

\section{References}

Allen RG, Pereira LS, Raes D, Smith M (1998) Crop evapotranspiration-guidelines for computing crop water requirements. FAO Irrigation and Drainage Papers 56. FAO, Rome

Almagro L, Custodio E (2004) Caracterización hidrogeoquímica de las aguas subterráneas de la Formación Chuy en la franja costera del Este del Uruguay fronteriza con Brasil. Bol Geol y Min 115:357-378 (Montevideo)

Auge M (2005) Hidrogeología de La Plata Provincia de Buenos Aires. In: de Barrio RE, Etcheverry RO, Caballé MF, Llambías EJ (eds) Geología y Recursos Minerales de la Provincia de Buenos Aires Relatorio del XVI Congreso Geológico Argentino. Asociación Geológica Argentina, La Plata, Buenos Aires, pp 293-326

Basile PA, Riccardi GA (2000) Procesos hidrológicos urbanos. In: Orsonino HE, Zimmermann ED, Basile PA (eds) Hidrología procesos y métodos. Universidad Nacional de Rosario, Rosario, pp 253-280

Batrak G, Semenov S (2008) Groundwater's dynamic regime in urban territories 33rd international geological congress abstract CD HYH-01 general contribution to hydrogeology. Oslo, Norway

Bellot J, Bonet A, Peña J, Sánchez J (2007) Human impacts on land cover and water balances in a coastal Mediterranean county. Environ Manage 39(3):412-422

Bocanegra E, Da Silva Cardoso, Jr G, Custodio E, Manzano M, Montenegro S (2010) State of knowledge of coastal aquifer management in South America. Hydrogeol J 118:261-267

Byrne GF, Crapper PF, Mayo KK (1980) Monitoring land-cover change by principal component analysis of multitemporal Landsat data. Remote Sens Environ 10:175-184

Carretero S (2011) Comportamiento hidrológico de las dunas costeras en el sector nororiental de la provincia de Buenos Aires. Unpublished doctoral thesis. Facultad de Ciencias Naturales y Museo, Universidad Nacional de La Plata, Argentina. http://sedici.unlp.edu.ar/bitstream/ handle/10915/4918/Documento_completo.pdf?sequence=1. Accessed 20 Nov 2014

Carretero S, Kruse E (2010) Modificaciones en las áreas de recarga del acuífero freático en los médanos costeros de San Clemente del Tuyú, provincia de Buenos Aires. Revista Asociación Geológica Argentina 66(4):466-474 (Buenos Aires)

Carretero S, Kruse E (2012) Relationship between precipitation and water-table fluctuation in a coastal dune aquifer: northeastern coast of the Buenos Aires province, Argentina. Hydrogeol J 20:1613-1621

Carretero S, Kruse E (2014) Impacto de la urbanización en la infiltración en un área costera, Argentina. Tecnología y Ciencias del Agua 5(6):5-24

Carretero S, Kruse E (2015) Iron and manganese content in groundwater on the northeastern coast of the Buenos Aires province, Argentina. Environ Earth Sci 73(5):1983-1995

Carretero S, Rapaglia J, Bokuniewicz H, Kruse E (2013a) Impact of sea level rise on saltwater intrusion length into the coastal aquifer, Partido de La Costa, Argentina. Cont Shelf Res 6162:62-70 
Carretero S, Dapeña C, Kruse E (2013b) Hydrogeochemical and isotopic characterisation of groundwater in a sand-dune phreatic aquifer on the northeastern coast of the province of Buenos Aires. Isot Environ Health Stud 49(3):399-419

Carretero S, Kruse E, Rojo A (2013c) Condiciones hidrogeológicas en Las Toninas y Santa Teresita, Partido de La Costa. In: González N, Kruse E, Trovatto MM, Laurencena P (eds) Temas actuales en hidrología subterránea. Editorial de la Universidad Nacional de La Plata (EDULP), La Plata, pp 28-35

Carretero S, Braga F, Kruse E, Tosi L (2014) Temporal analysis of the changes in the sand-dune barrier in the Buenos Aires Province, Argentina and their relationship with the water resources. Appl Geog 54:169-181

CFI (1990) Evaluación del Recurso Hídrico Subterráneo de la Región Costera Atlántica de la Provincia de Buenos Aires Región 1 Punta Rasa-Punta Médanos Informe Final Tomo 1 Hidrología Subterránea. CFI, Buenos Aires

Custodio E (2010) Coastal aquifers of Europe: an overview. Hydrogeol J 18:269-280

Chander G, Markham BL, Helder DL (2009) Summary of current radiometric calibration coefficients for Landsat MSS TM ETM+ and EO-1 ALI sensors. Remote Sens Environ 113:893-903

de Seoane CLV, Gallego Fernández JB, Vidal Pascual C (2007) Manual de restauración de dunas costeras. Ministerio de Medio Ambiente, Dirección General de Costas, Spain

FitzGerald DM, Buynevich IV (2006) Coastal barriers. In: Iribarne O, Isla F (eds) Coastal zone and estuaries. Encyclopedia of life support systems (EOLSS) developed under the Auspices of the UNESCO, Eolss Publishers Oxford, UK. http://www.eolss.net/outlinecomponents/CoastalZones-Estuaries.aspx. Accessed 21 Ago 2014

Hibbs BJ, Sharp JM Jr (2012) Hydrogeological impacts of urbanization. Environ Eng Geosci 18:3-24

Houlahan J, Findlay C (2004) Estimating the 'critical' distance at which adjacent land-use degrades wetland water and sediment quality. Landscape Ecol 19:677-690

Huang J, Gilmore Pontius R Jr, Li Q, Zhang Y (2012) Use of intensity analysis to link patterns with processes of land change from 1986 to 2007 in a coastal watershed of southeast China. Appl Geogr 34:371-384

INDEC (Instituto Nacional de Estadística y Censos de la República Argentina) (1981) Censo Nacional de Población Hogares y Viviendas, Buenos Aires. http://www.indec.gov.ar. Accessed 15 July 14

INDEC (Instituto Nacional de Estadística y Censos de la República Argentina) (2010) Censo Nacional de Población Hogares y Viviendas, Buenos Aires. http://www.indec.gov.ar. Accessed 15 July 14

Kim Y-Y (2004) Analysis of hydrochemical processes controlling the urban groundwater system in Seoul area, Korea. Geosci J 8(3):313-318

Kim Y, Lee K, Koh D, Lee D, Lee S, Park W, Koh G, Woo N (2003) Hydrogeochemical and isotopic evidence of groundwater salinization in a coastal aquifer: a case study in Jeju volcanic island, Korea. J Hidrogeol 270:282-294

Kruse E, Varela L, Laurencena P, Deluchi M, Rojo A, Carol E (2004) Modificaciones del ciclo hidrológico en un área del Noreste de la Provincia de Buenos Aires, Argentina. In: Junta Directiva AIH-GD (eds) Serie Hidrogeología y Aguas Subterráneas 11, Instituto Geológico Minero de España, Madrid

Kruse E, Carretero S, Pousa J, Guaraglia D (2012) Critical problems for the fresh water supply to summer resorts on the eastern coast of the Buenos Aires province Argentina. In: Rossi AE, Miranda LS (eds) Argentina: environmental geographical and cultural issues. Nova Science Publishers, New York

Kruse E, Carol E, Mancuso M, Laurencena P, Deluchi M, Rojo A (2013) Recharge assessment in an urban area: a case study of La Plata Argentina. Hydrogeol J 21:1091-1100

Kuleli T, Guneruglu A, Karsli F, Dihkan M (2011) Automatic detection of shoreline change on coastal Ramsar wetlands of Turkey. Ocean Eng 38:1141-1149

Lerner DN, Barrett MH (1996) Urban groundwater issues in the UK. Hydrogeol J 4:80-89 
Lerner DN (2002) Identifying and quantifying urban recharge: a review. Hydrogeol J 10:143-152

Manzano M (2002) El papel de los acuíferos costeros en la gestión del medio natural. In: Bocanegra E, Martínez D, Massone H (eds) Groundwater and human development. ALSHUD, Mar del Plata, pp 2017-2024

Martínez ML, Vázquez G (2006) Coastal sand dune and barrier island. In: Iribarne O, Isla F (eds) Coastal zone and estuaries. Encyclopedia of life support systems (EOLSS) developed under the Auspices of the UNESCO Eolss Publishers. Oxford, UK. http://www.eolss.net/ outlinecomponents/Coastal-Zones-Estuaries.aspx. Accessed 21 Ago 2014

Martínez ML, Psuty NP, Lubke RA (2008) A perspective on coastal dunes. In: Martínez ML, Psuty NP (eds) Coastal dunes ecology and conservation ecological studies, vol 171. Springer, Heidelberg, pp 3-10

Park S-S, Kim S-O, Yun S-T, Chae G-T, Yu S-Y, Kim S, Young K (2005) Effects of land use on the spatial distribution of trace metals and volatile organic compounds in urban groundwater Seoul, Korea. Environ Geol 48:1116-1131

Planas AC, Gaviño Novillo M, Mendiburo N, Calcagno A, Urbano Jáuregui L (2000) Informe sobre la gestión del agua en la República Argentina. JVP Consultores, Buenos Aires

Perdomo S, Carretero S, Kruse E, Ainchil J (2013) Identificación de la intrusión salina en Santa Teresita (Buenos Aires) mediante la aplicación de métodos eléctricos. In: González N, Kruse E, Trovatto MM, Laurencena P (eds) Temas actuales en hidrología subterránea. Editorial de la Universidad Nacional de La Plata (EDULP), La Plata, pp 44-49

Pousa J, Tosi L, Kruse E, Guaraglia D, Bonardi M, Rizzetto F, Schnack E (2007) Coastal processes and environmental hazards: the Buenos Aires (Argentina) and Venetian (Italy) Littorals. Environ Geol 51:1307-1316

Ray DK, Pijanowski BC, Kendall AD, Hyndman DW (2012) Coupling land use and groundwater models to map land use legacies: assessment of model uncertainties relevant to land use planning. Appl Geogr 34:356-370

Rebouças ADC (1999) Groundwater resources in South America. Episodes 22(3):232-237

Seiler K-P, Gat JR (2007) Man's impact on the groundwater recharge. Groundwater recharge from run-off infiltration and percolation. Springer, Netherlands, pp 187-200

Shalaby A, Tateishi R (2007) Remote sensing and GIS for mapping and monitoring land cover and land-use changes in the Northwestern coastal zone of Egypt. Appl Geogr 27:28-41

Sharp JM Jr (2010) The impacts of urbanization on groundwater systems and recharge AQUAmundi 1:51-56

Sharp JM, Krothe JN, Mather JD, Garcia-Fresca B, Stewart CA (2013) Effects of urbanization on groundwater systems. In: Heiken G, Fakundiny R, Sutter J (eds) Earth science in the city: a reader. American Geophysical Union, Washington DC

Song C, Woodcock CE, Seto KC, Lenney MP, Macomber SA (2001) Classification and change detection using Landsat TM data: when and how to correct atmospheric effects? Remote Sens Environ 75(2):230-244

Thornthwaite C, Mather J (1955) The water balance. Climatology 8:1-37

Vázquez Suñé E, Sánchez-Vila X (1997) Cálculo de balance y recarga en la ciudad de Barcelona. In: Custodio E, Llamas MR, Samper J (eds) La evaluación de la recarga a los acuíferos en la planificación hidrológica. Textos del Seminario celebrado en Las Palmas de Gran Canaria, Instituto Tecnológico Geominero de España, Madrid

Weng Q (2001) Modelling urban growth effects on surface runoff with the integration of remote sensing and GIS. Environ Manage 28(6):737-748

Wiles TJ, Sharp JM Jr (2008) The secondary permeability of impervious cover. Environ Eng Geosci 14:251-265

Zuquette L, Pejon O, Dos Santos Collares J (2004) Land degradation assessment based on environmental geoindicators in the Fortaleza metropolitan region state of Ceará, Brazil. Environ Geol 45:408-425 